\title{
Ether-cleaving enzyme and diol dehydratase involved in anaerobic polyethylene glycol degradation by a new Acetobacterium sp.
}

\author{
Edgar Schramm \& Bernhard Schink* \\ Lehrstuhl Mikrobiologie I der Eberhard-Karls-Universität, Auf der Morgenstelle 28, W-7400 Tübingen, \\ Germany. (* requests for offprints)
}

Key words: anaerobic degradation, ether cleavage reactions, corrinoids, Acetobacterium sp., polyethylene glycol acetaldehyde lyase

\begin{abstract}
A strictly anaerobic, homoacetogenic bacterium was enriched and isolated from anoxic sewage sludge with polyethylene glycol (PEG) 1000 as sole source of carbon and energy, and was assigned to the genus Acetobacterium on the basis of morphological and physiological properties. The new isolate fermented ethylene glycol and PEG's with molecular masses of 106 to 1000 to acetate and small amounts of ethanol. The PEG-degrading activity was not destroyed by proteinase $K$ treatment of whole cells. In cell-free extracts, a diol dehydratase and a PEG-degrading (ether-cleaving) enzyme activity were detected which both formed acetaldehyde as reaction product. The diol dehydratase enzyme was oxygen-sensitive and was stimulated 10-14 fold by added adenosylcobalamine. This enzyme was found mainly in the cytoplasmic fraction (65\%) and to some extent (35\%) in the membrane fraction. The ether-cleaving enzyme activity reacted with PEG's of molecular masses of 106 to more than 20000 . The enzyme was measurable optimally in buffers of high ionic strength (4.0), was extremely oxygen-sensitive, and was inhibited by various corrinoids (adenosylcobalamine, cyanocobalamine, hydroxocobalamine, methylcobalamine). This enzyme was found exclusively in the cytoplasmic fraction. It is concluded that PEG is degraded by this bacterium inside the cytoplasm by a hydroxyl shift reaction, analogous to a diol dehydratase reaction, to form an unstable hemiacetal intermediate. The name polyethylene glycol acetaldehyde lyase is suggested for the responsible enzyme.
\end{abstract}

Abbreviations: EG - ethylene glycol, DiEG - diethylene glycol, TriEG - triethylene glycol, TeEG - tetraethylene glycol, PEG - polyethylene glycol (molecular mass indicated)

\section{Introduction}

Polyethylene glycol (PEG) is an important constituent of many industrial products including lubricants, antifreeze agents, pharmaceuticals, cosmetics, and nonionic tensides. In the latter, it acts as hydrophilic moiety, and is discharged into the environment at high rates (Bock \& Stache 1982; Steber $\&$ Wierich 1985). The annual worldwide produc- tion of PEG's is in the range of 1 million metric tons (Houston 1981). The comparably high stability of these compounds is due to the aliphatic ether linkages which cause considerable problems to microbial degradation.

Aerobic PEG degradation was observed with several bacterial isolates (Cox 1978; Kawai 1987), and was studied in detail mainly with a mixed culture of a Flavobacterium and a Pseudomonas strain 
(Kawai 1985; Kawai et al. 1985; Kawai 1987). In these bacteria, the terminal alcohol function is first oxidized via the aldehyde to the carboxylic acid derivative, and a glyoxylic acid residue is finally released through a carbon-oxygen lyase reaction by a dehydrogenase (Kawai 1985). Since at least two oxidations in this reaction sequence are linked to pyrroloquinoline quinone (Kawai et al. 1985), an electron acceptor of comparably high redox potential $\left(E_{o}{ }^{\prime}=+120 \mathrm{mV}\right.$; Duine et al. 1986), such a degradation pathway cannot be used by strictly anaerobic fermenting or sulfate-reducing bacteria. A different pathway of PEG degradation employing desaturation and hydratation to a hemiacetal derivative was postulated but never experimentally confirmed (Thélu et al. 1981).

Anaerobic degradation of PEG's was studied with fermenting (Schink \& Stieb 1983; Dwyer \& Tiedje 1983; 1986; Wagener \& Schink 1988), denitrifying (Grant \& Payne 1983), and sulfate-reducing bacteria (Dwyer \& Tiedje 1986), and appears to proceed in a basically different manner. Acetaldehyde was identified as the first reaction product in a denitrifying bacterium (Pearce \& Heydeman 1980), and with dense cell suspensions of a fermenting bacterium, Pelobacter venetianus (Straß \& Schink 1986). These observations suggested a reaction mechanism analogous to a diol dehydratase enzyme (Schink \& Stieb 1983; Straß \& Schink 1986), however, the responsible enzyme system could not yet be demonstrated in cell-free extracts. A different way of degradation through hydrolysis or 'hydrogenation' was suggested for a Bacteroides and a Desulfovibrio strain (Dwyer \& Tiedje 1986) but never experimentally proven.

In the present study, a PEG-degrading enzyme forming acetaldehyde as product is demonstrated for the first time in cell-free extracts of a strictly anaerobic bacterium.

\section{Materials and methods}

\section{Organism and cultivation}

Acetobacterium sp. strain HA1 was isolated from anoxic sewage sludge obtained from the municipal sewage treatment plant at Marburg-Cappel, Germany.

All procedures for cultivation and isolation as well as all methods for analysis of metabolic products were essentially as described in earlier papers (Widdel \& Pfennig 1981; Schink \& Pfennig 1982). The mineral medium for enrichment, isolation, and cultivation contained $30 \mathrm{mM}$ sodium bicarbonate buffer, $1 \mathrm{mM}$ sodium sulfide as reducing agent, the trace element solution SL 10 (Widdel et al. 1983), and a 6 vitamin solution (Pfennig 1978) not containing vitamin $\mathrm{B}_{12}$. The $\mathrm{pH}$ was $7.1-7.3$, and the incubation temperature $30^{\circ} \mathrm{C}$. For isolation of pure cultures, the agar shake dilution method was applied (Pfennig 1978). Gram staining was carried out after Magee et al. (1975).

For enzyme assays, cultures were grown in $1000 \mathrm{ml}$ infusion bottles filled with mineral medium containing $5 \mathrm{mM}$ TriEG, and gassed with $\mathrm{N}_{2} / \mathrm{CO}_{2}$ $(80 / 20 \%)$. Further $5 \mathrm{mM}$ TriEG was added after $12-20 \mathrm{~h}$. After about $36 \mathrm{~h}$ of cultivation, cells were harvested in the late $\log$ phase at $\mathrm{OD}_{578}=0.3$ by centrifugation at $3000 \times \mathrm{g}$ for $20 \mathrm{~min}$. in $100 \mathrm{ml}$ infusion bottles under $\mathrm{N}_{2} / \mathrm{CO}_{2}$ at $4^{\circ} \mathrm{C}$ in a Sorvall centrifuge rotor equipped with rubber adapters.

\section{Preparation of cell-free extracts}

All manipulations of cell material were performed under a nitrogen atmosphere, preventing any access of air. Cells of 11 culture medium were washed in $50 \mathrm{ml} 50 \mathrm{mM}$ potassium phosphate buffer, $\mathrm{pH}$ 8.0 , containing either $2 \mathrm{mM}$ dithioerythritol or $3 \mathrm{mM}$ titanium citrate (Zehnder \& Wuhrmann 1976), and were resuspended in $2 \mathrm{ml}$ of the same buffer. Cells were broken by 4-5 runs through a special strictly anoxic French press at $140 \mathrm{MPa}$ pressure until nearly no intact cells were detectable any more by microscopic control. The cell homogenate was centrifuged in oxygen-free vials for 10 min at $10000 \times \mathrm{g}$ to remove intact cells. For some experiments, the supernatant crude extract was dialyzed at $4^{\circ} \mathrm{C}$ against 21 of the same buffer for $36 \mathrm{~h}$ with vigorous stirring to remove endogenous 
cofactors. For localization experiments, the crude extract was separated into a cytoplasmic and a membrane fraction by anoxic centrifugation at $200000 \times \mathrm{g}$ for $1 \mathrm{~h}$ (Model LS 50 ultracentrifuge, Beckman Instruments, München, Germany). The supernatant was decanted and the pellet resuspended in the same volume of the homogenization buffer. For analysis of separation efficiency, both fractions were subjected to sodium dodecylsulfate polyacrylamide gel electrophoresis (Lugtenberg et al. 1975). Non-denaturing electrophoresis of intact proteins was carried out after Davis (1964).

PEG degradation experiments in dense cell suspensions

Cell suspensions grown to the late log phase (see above) were concentrated by centrifugation in infusion bottles to a cell density of $\mathrm{OD}_{578}=14-16$, and transferred by syringes into $2 \mathrm{ml}$ serum vials under nitrogen atmosphere. Substrates $(10 \mathrm{mM}$ TriEG, $0.1 \%$ PEG) were added from concentrated anoxic stock solutions by syringes, and the suspensions were incubated at $25^{\circ} \mathrm{C}$. Samples were taken for analysis of reaction products by syringes, preserved by addition of formic acid to $0.5 \mathrm{M}$ final concentration, and stored at $-18^{\circ} \mathrm{C}$ before assay. Extracellular enzyme activities were checked for by addition of proteinase $\mathrm{K}(2 \mathrm{U} / \mathrm{ml}$; Boehringer, Mannheim, Germany) and incubation at $25^{\circ} \mathrm{C}$ for $20 \mathrm{~min}$ before assay. Controls were run with yeast ethanol dehydrogenase in the same manner.

\section{Enzyme assays}

All enzyme assays were carried out with a Hitachi Model 100-40 variable wavelength spectrophotometer (Hitachi, Tokyo, Japan) at $25^{\circ} \mathrm{C}$ in rubberstoppered cuvettes under nitrogen atmosphere. Buffers and substrate solutions were kept anoxic prior to addition by hypodermic syringes. Diol dehydratase was measured as NADH-dependent acetaldehyde reduction in a coupled assay after Toraya et al. (1979) in $50 \mathrm{mM}$ potassium phosphate buffer, pH 8.0, containing $2 \mathrm{mM}$ dithioerythritol. The reaction was started by addition of either $100 \mathrm{mM}$ EG or of $10 \mu \mathrm{M}$ coenzyme $\mathrm{B}_{12}$. The PEGdegrading enzyme was assayed in a similar manner in $1.0 \mathrm{M}$ potassium phosphate buffer, $\mathrm{pH} 8.0$, containing $3 \mathrm{mM}$ titanium citrate. The reaction was started by addition of $75 \mathrm{mM}$ TriEG or $75 \mathrm{mM}$ TeEG from anoxic $1 \mathrm{M}$ stock solutions. Reaction rates in the presence and absence of cofactors (corrinoids) were compared before and after cofactor addition.

Carbon monoxide dehydrogenase was assayed with methyl viologen as electron acceptor (Diekert \& Thauer 1978).

\section{Chemical analyses}

Acetaldehyde, ethanol, and acetate were identified and quantified with a Vega 6000 gas chromatograph (Carlo Erba Strumentazione, Milano, Italy) equipped with a flame ionization detector and a $2 \mathrm{~m} \times 2 \mathrm{~mm}$ glass column packed with $60 / 80$ Carbopak C/0.3\% Carbowax 20 M/0.1\% $\mathrm{H}_{3} \mathrm{PO}_{4}$ (Supelco Inc., Bellefonte, PA, USA), injector and detector temperature $200^{\circ} \mathrm{C}$, temperature program 80 $160^{\circ} \mathrm{C}$, carrier gas nitrogen at $40 \mathrm{ml} / \mathrm{min}$. Samples were acidified with formic acid ( $0.5 \mathrm{M}$ final concentration) prior to injection. EG, DiEG and TriEG were separated with the same gas chromatograph on a $1 \mathrm{~m} \times 2 \mathrm{~mm}$ column packed with Chromosorb 101, 100/200 mesh (AllTech Ass. Inc., Deerfield, IL, USA), injector and detector temperature $250^{\circ} \mathrm{C}$, column temperature $190-210^{\circ} \mathrm{C}$. Protein was quantified after Bradford (1976).

\section{Chemicals}

All chemicals used were of analytical grade quality and obtained from Fluka, Neu Ulm, and Merck, Darmstadt, Germany. PEG's were purchased as follows: from Merck, Darmstadt: PEG's 200 and 400, technical grade; from Fluka, Neu Ulm: PEG's $300,1000,10000$, and 20000, technical grade, and DiEG and TriEG, analytical grade; from Hoechst, 
Gendorf, Germany: DiEG, TriEG, and TeEG, analytical grade; from Serva, Heidelberg, Germany: PEG's 6000, 40000. Biochemicals were obtained from Boehringer, Mannheim, Germany, corinoids from Sigma, München, Germany.

\section{Results}

\section{Isolation and characterization of strain $H A l$}

Enrichment cultures with mineral medium containing PEG 1000 as sole source of carbon and energy were inoculated with sewage sludge from a municipal sewage plant. Gas formation and bacterial growth started after 10-15 days; subcultures grew up within 2-3 days and did not form significant amounts of gas. Pure cultures of PEG-degrading bacteria were obtained by two subsequent agar shake dilutions with PEG 1000 as substrate. Colonies in the agar were elliptical, $0.2-0.5 \mathrm{~mm}$ in diameter, and slightly yellow. Cells were rod-shaped with pointed ends, $1.5 \times 2.5-3.5 \mu \mathrm{m}$ in size (Fig. 1 ), and motile in young cultures in a characteristic tumbling manner. Gram staining and Gram typing both were indicative of a Gram positive cell wall architecture. EG, DiEG, TriEG and PEG's up to a

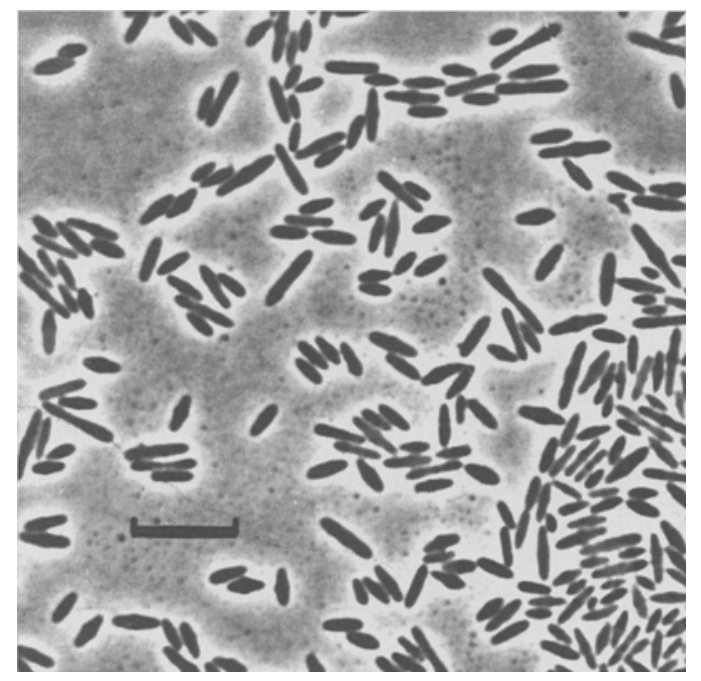

Fig. 1. Phase contrast photomicrograph of cells of Acetobacteri$u m$ strain HAI grown with TriEG. Bar equals $5 \mu \mathrm{m}$. molecular mass of 1000 were fermented to acetate and traces of ethanol (Table 1). Methoxylated and ethoxylated EG's and PEG's were not degraded. Growth was also possible with fructose, formate, and hydrogen $/ \mathrm{CO}_{2}$; these substrates were fermented to acetate as well. Glycerol fermentation led to acetate and 1,3-propanediol. Growth was optimal with $0.1-0.2 \%$ PEG 1000 with a generation time of $12 \mathrm{~h}$ at $30^{\circ} \mathrm{C}$. High activities of carbon monoxide dehydrogenase ( $4.3 \mathrm{U}$ per $\mathrm{mg}$ protein) were detected in cell-free extracts.

\section{PEG degradation in dense cell suspensions}

Dense cell suspensions incubated with PEG 1000 produced acetate at a constant rate of $0.3 \mu \mathrm{mol}$. mg protein ${ }^{-1} \cdot \min ^{-1}$ (Fig. 2), which is in the same range as acetate formation in cells growing optimally with TriEG $\left(0.25 \mu \mathrm{mol} \cdot \mathrm{mg}\right.$ protein $^{-1}$. $\min ^{-1}$ ). Acetaldehyde accumulated transiently up to $15 \mathrm{mM}$ concentration, and was degraded later after PEG was exhausted. DiEG and EG appeared transiently at low concentrations $(<0.1 \mathrm{mM}$, not shown). Proteinase $\mathrm{K}$ had no influence on the degradation rate in these experiments, but destroyed added ethanol dehydrogenase immediately.

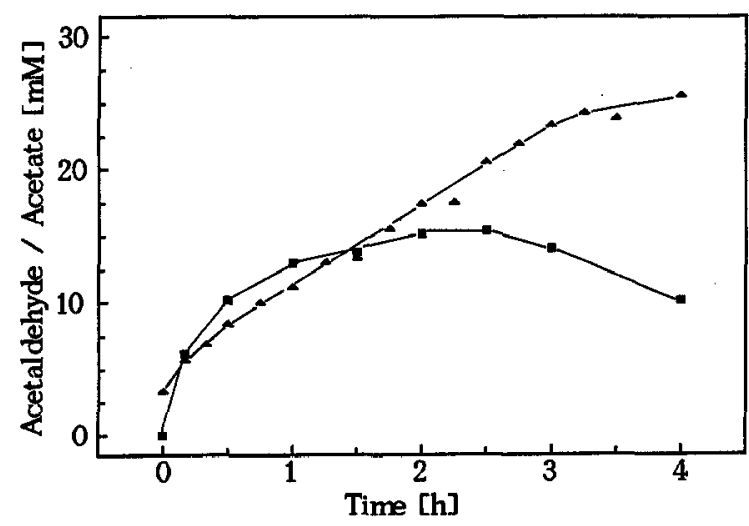

Fig. 2. Formation of acetate ( $\boldsymbol{\Delta}$ ) and acetaldehyde ( $\boldsymbol{E})$ by a dense cell suspension $\left(\mathrm{OD}_{578}=16\right)$ of Acetobacterium strain $\mathrm{HAI}$ in the presence of $0.5 \% \mathrm{PEG} 1000$. 
Characterization of the diol dehydratase activity

A diol dehydratase activity (1,2-propanediol hydro-lyase, E.C. 4.2.1.28; International Union of Biochemistry 1984) which reacted with ethylene glycol to form acetaldehyde was found at high activity in cell-free extracts of PEG-grown cells (Table 2). The enzyme was stimulated $10-14$ fold by addition of adenosylcobalamine (coenzyme $B_{12}$ ) as cofactor; other corrinoids (cyanocobalamine, hydroxocobalamine, methylcobalamine) inhibited the enzyme reaction when added to the same reaction mixture. In the presence of adenosylcobalamine, the reaction rate was constant for more than $10 \mathrm{~min}$. (Fig. 3a); adenosylcobalamine additions in the range of $0.1-100 \mu \mathrm{M}$ yielded identical reaction rates, and dialysis of crude extract prior to enzyme measurement did not increase the stimulation effect. Cations $\left(\mathrm{Mg}^{2+}>\mathrm{Na}^{+}>\mathrm{RB}^{+}>\mathrm{K}^{+}\right.$, each at $40 \mathrm{mM}$ concentration) inhibited the enzyme by
$69 \%, 41 \%, 35 \%$, and $16 \%$, respectively. $40 \mathrm{mM}$ $\mathrm{NH}_{4}{ }^{+}$caused a stimulation by $6 \%$; glycerol caused complete inhibition at $50-100 \mathrm{mM}$ concentration. The enzyme was sensitive to oxygen (about 50\% inactivation during $4 \mathrm{~h}$ under air); this sensitivity could be alleviated slightly by addition of propanediol in the storage buffer. In localization experiments, about one third of the activity was found to be bound to the membrane, and two thirds were found in the cytoplasmic fraction.

\section{Characterization of the ether-cleaving enzyme activity}

Contrary to the diol dehydratase activity, the ether-cleaving enzyme (measured as acetaldehyde formation from TriEG or higher PEG's) was stimulated by enhanced ion concentrations in the assay buffer, with an optimum at $1.0-1.5 \mathrm{M}$ potassium

Table 1. Growth yields and substrate conversion stoichiometry with Acetobacterium strain HA1.

\begin{tabular}{|c|c|c|c|c|c|c|c|}
\hline \multirow[t]{2}{*}{ Substrate } & \multirow{2}{*}{$\begin{array}{l}\text { Amount } \\
\text { per liter }\end{array}$} & \multirow{2}{*}{$\begin{array}{l}\mathrm{OD}_{546} \\
\text { reached }\end{array}$} & \multirow{2}{*}{$\begin{array}{l}\text { Substrate } \\
\text { provided } \\
(\mu \mathrm{mol})^{\mathbf{a}}\end{array}$} & \multicolumn{2}{|c|}{ Products $(\mu \mathrm{mol})$} & \multirow{2}{*}{$\begin{array}{l}\text { Growth } \\
\text { yield } \\
\mathrm{g} \cdot \mathrm{mol}^{-\mathbf{l b}}\end{array}$} & \multirow{2}{*}{$\begin{array}{l}\text { Electron } \\
\text { recovery } \\
(\%)\end{array}$} \\
\hline & & & & Acetate & Ethanol & & \\
\hline $\mathrm{EG}$ & $20 \mathrm{mmol}$ & 0.23 & 460 & 486 & 9 & 4.6 & 94 \\
\hline DiEG & $10 \mathrm{mmol}$ & 0.22 & 460 & 462 & 1 & 4.3 & 87 \\
\hline TriEG & $10 \mathrm{mpmol}$ & 0.34 & 690 & 823 & 5 & 4.5 & 101 \\
\hline PEG 200 & $1.0 \mathrm{~g}$ & 0.23 & 479 & 483 & n.d. & 4.4 & 88 \\
\hline PEG 400 & $1.0 \mathrm{~g}$ & 0.25 & 500 & 400 & 16 & 4.6 & 74 \\
\hline PEG 1000 & $1.0 \mathrm{~g}$ & 0.29 & 506 & 375 & 44 & 5.1 & 79 \\
\hline Brij-35 & $1.0 \mathrm{~g}$ & 0.10 & - & 345 & n.d. & - & - \\
\hline Glycerol & $10 \mathrm{mmol}$ & 0.18 & 230 & 85 & n.d. & 7.0 & $41^{\mathrm{d}}$ \\
\hline $\mathrm{H}_{2} / \mathrm{CO}_{2}{ }^{\mathrm{e}}$ & & 0.10 & 892 & 190 & n.d. & 0.4 & 107 \\
\hline Formate & $20 \mathrm{mmol}$ & 0.10 & 460 & 87 & n.d. & 2.0 & 92 \\
\hline Fructose & $2 \mathrm{mmol}$ & 0.25 & 46 & 115 & $<1$ & 51.0 & 101 \\
\hline
\end{tabular}

n.d. means 'not determined'.

All figures are means of at least 3 independent assays.

No growth was found with any of the following substrates (provided at 5-10 mM concentrations): PEG 6000-20 000, Tween-80, Triton $\mathrm{X}-100$, Brij-58, ethoxyethanol, methoxyethanol, phenoxyethanol, phenoxyacetate, dimethoxyethane, tetraethylene glycol dimethylether, methanol, ethanol, ethanolamine, glucose, arabinose, xylose, and yeast extract.

Growth with trimethoxybenzoate was possible, but substrate degradation was incomplete and not always reproducible.

${ }^{\text {a }}$ For PEG's, substrate provided was calculated as EG monomers.

${ }^{b}$ Growth yields were calculated via cell density and an experimentally determined conversion factor $\left(\mathrm{OD}_{546}=0.1 \mathrm{refers}\right.$ to $41 \mathrm{mg}$ dry matter $\left.\cdot 1^{-1}\right)$

${ }^{c}$ Total electron recovery also includes the amount of electrons assimilated into cell material, as calculated via the equation: $19 \mathrm{C}_{2} \mathrm{H}_{6} \mathrm{O}_{2}+$ $8 \mathrm{HCO}_{3} \rightarrow 6<\mathrm{C}_{4} \mathrm{H}_{7} \mathrm{O}_{4}+11 \mathrm{CH}_{3} \mathrm{COO}^{-}+3 \mathrm{H}^{+}+22 \mathrm{H}_{2} \mathrm{O}$.

${ }^{\mathrm{d}}$ Propanediol was formed as a byproduct, but was not quantified.

${ }^{\mathrm{e}} \mathrm{H}_{2} / \mathrm{CO}_{2}(80 \% / 20 \%)$ was provided in the headspace of a half-filled culture tube. 


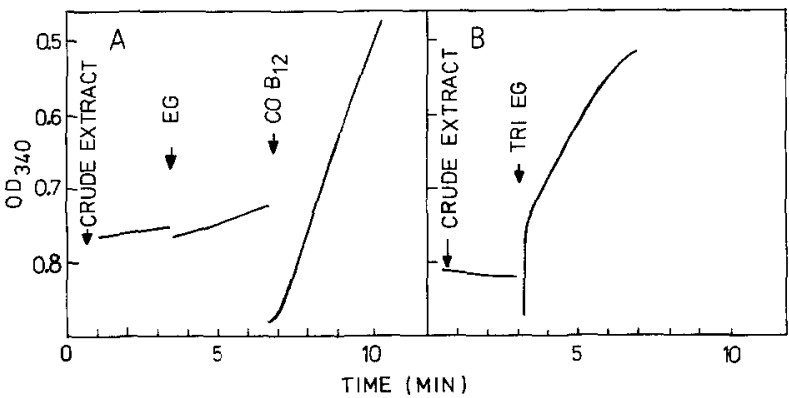

Fig. 3. Time courses of a) diol dehydratase and b) PEG acetaldehyde lyase reaction in an optical test coupled via ethanol dehydrogenase to NADH-dependent acetaldehyde reduction. Details of the test assay are described in the Materials and Methods section.

phosphate (Fig. 4), or $0.05 \mathrm{M}$ potassium phosphate plus $4 \mathrm{M} \mathrm{KCl}$. The enzyme was also extremely oxygen-sensitive and was destroyed by exposure to air within 2-5 min. For the enzyme assay, a low redox potential was required: optimal results were obtained with $2-3 \mathrm{mM}$ titanium citrate as reductant; with $2 \mathrm{mM}$ dithioerythritol, only about $10 \%$ of the activity of the titanium citrate-reduced assay was achieved. Even under optimal conditions, the reaction rate was constant only for short periods (about $1 \mathrm{~min}$. Fig. 3b) after substrate addition, and

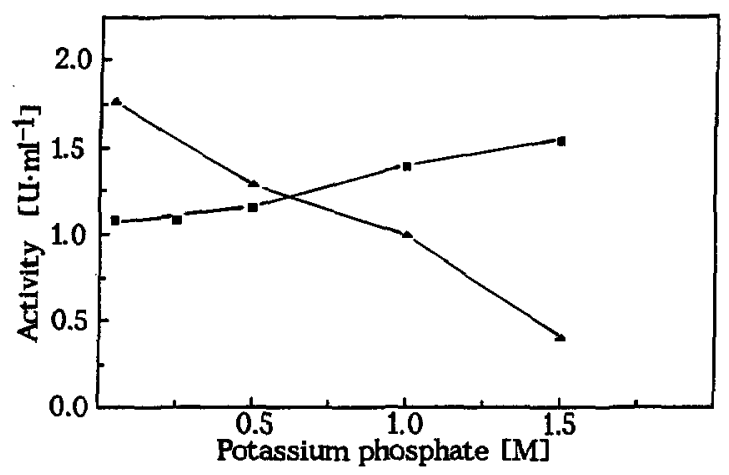

Fig. 4. Influence of the potassium phosphate buffer concentration on the measurable activities of dioldehydratase $(\boldsymbol{\Delta})$ and ether-cleaving enzyme ( $\mathbf{\square})$.

declined exponentially afterwards. Corrinoids did not stimulate the reaction rate; rather, all corrinoids tested inhibited acetaldehyde formation entirely at $10 \mu \mathrm{M}$ concentration. Glycerol inhibited acetaldehyde formation from PEG only slightly. The enzyme activity was found exclusively in the cytoplasmic fraction.

The reaction rate differed with different PEG's tested (Table 3). Maximum specific activities were measured with PEG's 200-1000. Higher molecular mass PEG's were degraded as well, but obviously

Table 2. Comparison of diol dehydratase and ether-cleaving enzyme in cell extracts of Acetobacterium strain HAI.

\begin{tabular}{|c|c|c|}
\hline & Diol dehydratase & Ether-cleaving enzyme \\
\hline Substrate specificity & Ethylene glycol, 1,2-Propanediol & $\begin{array}{l}\mathrm{H}\left(\mathrm{OCH}_{2} \mathrm{CH}_{2}\right)_{\mathrm{n}} \mathrm{OH} \mathrm{n}=2 \rightarrow 454 \\
(\mathrm{PEG} \mathrm{20} \mathrm{000),} \mathrm{Ethoxyethanol}\end{array}$ \\
\hline Specific activity (U/mg) & for EG: 1.6 & for TriEG: 6.3 \\
\hline Linearity of the reaction & $>12 \mathrm{~min}$ & $<1 \mathrm{~min}$ \\
\hline Apparent $\mathrm{Km}(\mathrm{mM})$ & for EG: 12 & n.d. \\
\hline pH optimum & $7.4-8.1$ & $7.0-8.0$ \\
\hline Influence of corrinoids $(10 \mu \mathrm{M})$ & $\begin{array}{l}10-14 \text { fold stimulation by } \\
\text { adenosylcobalamin }^{\mathrm{a}}\end{array}$ & $6-100 \%$ inhibition by all corrinoids tested ${ }^{b}$ \\
\hline Preferred ionic strength & $<0.15$ & $>4.15$ \\
\hline Inhibition by glycerol $(100 \mathrm{mM})$ & $100 \%$ & $10 \%$ \\
\hline \multicolumn{3}{|l|}{ Localization } \\
\hline Membrane fraction & $34.5 \%$ & - \\
\hline Soluble fraction & $65.5 \%$ & $100 \%$ \\
\hline
\end{tabular}

${ }^{a}$ In the coupled assay with adenosylcobalamin $(100 \%)$, the diol dehydratase was inhibited by $\mathrm{CN}-\mathrm{B}_{12}(16 \%), \mathrm{OH}-\mathrm{B}_{12}(44 \$)$ and $\mathrm{CH}_{3}-\mathrm{B}_{12}$ (43\%), at concentrations of $10 \mu \mathrm{M}$.

${ }^{b}$ The degree of inhibition varied with the crude extract preparations. Total inhibition was achieved by $\mathrm{CN}-\mathrm{B}_{12}, \mathrm{OH}-\mathrm{B}_{12}$ and $\mathrm{CH}_{3}-\mathrm{B}_{12}$ at $10 \mu \mathrm{M}$ concentration. 
the reaction rate was limited by the actual concentration of substrate molecules.

\section{Discussion}

In the present study, a PEG-degrading, ethercleaving enzyme in cell-free extracts of a strictly anaerobic fermenting bacterium is described for the first time. A new PEG-degrading homoacetogenic bacterium was enriched and isolated for these experiments. This isolate is assigned to the genus Acetobacterium on the basis of morphological, physiological, and biochemical properties. In an earlier study (Wagener \& Schink 1988), another Acetobacterium-like bacterium was isolated with the PEG-containing surfactant Brij 58 as substrate, however, this strain was not easy to maintain on this substrate. Among the Acetobacterium species known, our new isolate strain HA1 resembles $A$. wieringae most on the basis of its substrate utilization spectrum (see Schink \& Bomar 1991).

Together with the ether-cleaving enzyme activity, we found in cell-free extracts a slightly lower diol dehydratase activity. This enzyme resembles very much the corresponding enzyme from Klebsiella pneumoniae ATCC 8724 (Toraya et al. 1979; Toraya \& Fukui 1982): Both enzymes use EG and 1,2-propanediol as substrates, and are inactivated by glycerol. Unlike the Klebsiella enzyme, the enzyme activity of strain HA1 is impaired rather than

Table 3. Specific activities of the ether-cleaving enzyme for different PEG species.

\begin{tabular}{lccc}
\hline Substrate & \multicolumn{2}{l}{ Concentration } & $\begin{array}{l}\text { Specific } \\
\text { activity } \\
\left(\mathrm{U} \cdot \mathrm{mg}^{-1}\right)\end{array}$ \\
\cline { 2 - 4 } & $\mathrm{g} \cdot \mathrm{1}^{-1}$ & $\mathrm{mM}^{\mathrm{a}}$ & \\
\hline DiEG & 10.6 & 100 & 9.7 \\
TriEG & 11.25 & 75 & 6.3 \\
TeEG & 14.55 & 75 & 18.9 \\
PEG 400 & 1.0 & 2.5 & 27.0 \\
PEG 1000 & 1.0 & 1.0 & 24.7 \\
PEG 6000 & 1.0 & 0.16 & 8.6 \\
PEG 10000 & 1.0 & 0.1 & 7.1 \\
PEG 20000 & 1.0 & 0.05 & 3.1 \\
\hline
\end{tabular}

${ }^{\mathrm{a}} \mathrm{mM}$ concentration of the polymer.

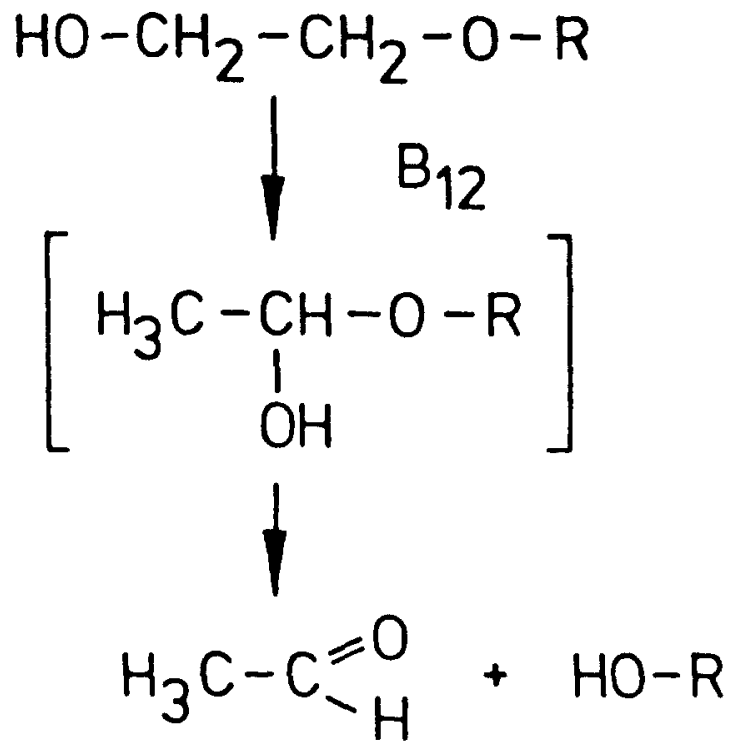

Fig. 5. Suggested reaction scheme of polyethylene glycol acetaldehyde lyase.

enhanced by most monovalent cations. Diol dehydratases catalyze the dehydratation of 1,2-diols by a hydroxyl substituent shift and formation of an aldehyde hydrate (Toraya \& Fukui 1982). An analogous reaction mechanism was postulated to underlie ether cleavage during PEG degradation: Since acetaldehyde was found to be the first product of PEG degradation, the polymer must be attacked by a hydroxyl shift reaction analogous to the diol dehydratase reaction forming the hemiacetal of acetaldehyde which may disintegrate non-enzymatically to yield the free aldehyde (Fig. 5). This concept was first suggested by Pearce and Heydeman (1980) for PEG degradation by an aerobic bacterium, and it was further supported by growth experiments with Pelobacter venetianus (Schink \& Stieb 1983; Straß \& Schink 1986). The findings that tetraethylene glycol dimethyl-ether, which does not contain a free hydroxyl group, cannot be degraded by this enzyme, and that the ether-cleaving enzyme is specifically inhibited by glycerol and by various corrinoids at micromolar concentrations both corroborate further this idea. Such a new type of ether-cleaving enzyme should be termed 'polyethylene glycol acetaldehyde lyase', analogous to, 
e.g., ethanolamine ammonia lyase, and would have to be listed among the carbon oxygen lyases in the 4.2. series of the E.C. system (International Union of Biochemistry 1984).

Our results provide evidence for the existence of a specific $P E G$ ether-cleaving enzyme activity in our isolate, together with a diol dehydratase enzyme activity which degrades the terminal EG unit appearing to the end of PEG chain decomposition. The data compiled in Table 2 indicate strongly that these two different enzyme reactions are catalyzed by two different enzyme proteins. This is supported by differences in substrate specificity, susceptibility to inhibition by various corrinoids, by oxygen, and by glycerol, activity at different ionic strength regimes, and different localization in the cell. The observed differences in the reaction kinetics are not necessarily an indication for the existence of two separate enzymes: Also the ethanolamine ammonia lyase of Escherichia coli exhibits a linear reaction for several minutes, whereas with (S)-2aminopropanol an exponentially decreasing reaction rate was observed (Babior 1982). More conclusive evidence for the existence of two separate enzymes could perhaps be provided by gel electrophoretic separation of both activities, however, all efforts to identify enzymatically active bands in non-denaturating electrophoresis gels have failed so far due to enzyme instability or enzyme destruction during non-denaturing electrophoresis.

There is no doubt that such a corrinoid-dependent hydroxyl shift reaction can occur only in the cytoplasm of bacterial cells, not outside the cytoplasmic membrane. In our experiments, the ethercleaving enzyme could not be destroyed outside the cell by proteinase $\mathrm{K}$ treatment; moreover, the degradative activity was much more susceptible to oxygen toxicity in cell extracts than in suspensions of intact cells. The substrate range of the ethercleaving enzyme in cell-free extracts of strain HAI was much broader than that of intact cells indicating that the cell envelope restricted access of high molecular mass PEG's to the enzyme molecule, and acetaldehyde, the first product of PEG degradation, accumulated inside the cells of $P$. venetianus (Straß \& Schink 1986). All these observations indicate that PEG's have to enter the cell before degradation, and the question remains how synthetic polymers with molecular masses up to $1000 \mathrm{D}$ (with $P$. venetianus up to $20000 \mathrm{D}$ ) can cross the cytoplasmic membrane. Also aerobic PEG degradation occurs inside the bacterial cells (Kawai 1987). The only report on extracellular PEG depolymerization by a hydrolyzing enzyme (Haines and Alexander 1975) could never be reproduced (Cox 1978; Kawai 1987).

Isolation of another Gram-positive anaerobic PEG-degrading bacterium which is metabolically distinct from the Gram-negative isolates $P$. venetianus (Schink and Stieb 1983), Bacteroides sp. and Desulfovibrio sp. (Dwyer \& Tiedje 1988), or a propionate-forming fermenting bacterium (Wagener \& Schink 1988) demonstrates that the capability to degrade such an unusual, comparably stable synthetic polymer is rather widespread among anaerobic bacteria, and numerous aerobic PEGdegrading bacteria (Cox 1978; Kawai 1987) further add to this diversity. For the anaerobic PEG-degrading enzyme described in this communication, it can be speculated that this new metabolic capacity was developed by modification of a diol dehydratase enzyme. Nearly all PEG-degrading anaerobes described so far contain also a diol dehydratase enzyme. Nonetheless, we did not succeed yet in attempts to produce a PEG-degrading capacity in EG-degrading bacteria ( $K$. pneumoniae, $A$. woodii) by simple mutagenization experiments with alkylating agents (unpublished results).

\section{Acknowledgements}

The authors are indebted to Dr. Saburo Fukui, Kyoto, Japan, for inspiring discussions, and to Dr. Erhard Stupperich, Ulm, for samples of various corrinoids and for helpful suggestions. This study was supported by the Fonds der Chemischen Industrie, Frankfurt/M., Germany.

\section{References}

Babior BM (1982) Ethanolamine ammonia-lyase. In: Dolphin 
D (Ed) $B_{12}$, Vol 2 (pp 264-286). John Wiley and Sons, New York

Bock KJ \& Stache H (1982) Surfactants. In: Hutzinger O (Ed) The Handbook of Environmental Chemistry, Vol 3B (pp 163-199). Springer, Berlin

Bradford M (1976) A rapid and sensitive method for the quantification of microgram quantities of protein utilizing the principle of protein-dye binding. Anal. Biochem. 72: 248-254

Cox DP (1978) The biodegradation of polyethylene glycols. Adv. Appl. Microbiol. 23: 173-194

Davis BJ (1964) Disc electrophoresis. II. Method and application to human serum proteins. Ann. NY Acad. Sci. 121: 404-427

Diekert GB \& Thauer RK (1978) Carbon monoxide oxidation by Clostridium thermoaceticum and Clostridium formicoaceticum. J. Bacteriol. 136: 597-606

Duine JA, Frank JJ \& Jongejan JA (1986) PQQ and quinoprotein enzymes in microbial oxidations. FEMS Microbiol. Rev. 32: $165-178$

Dwyer D \& Tiedje JM (1983) Degradation of ethylene glycol and polyethylene glycols by methanogenic consortia. Appl Environ. Microbiol. 46: 185-190

Dwyer D \& Tiedje JM (1986) Metabolism of polyethylene glycol by two anaerobic bacteria, Desulfovibrio desulfuricans and a Bacteroides sp. Appl. Environ. Microbiol. 52: 852-856

Grant MA \& Payne WJ (1983) Anaerobic growth of Alcaligenes faecalis var. denitrificans at the expense of ether glycols and nonionic detergents. Biotechnol. Bioeng. 25: 627-630

Houston CA (1981) Detergent alcohols in the news. J. Am. Oil. Chem. Soc. 58: 873a-874a

Haines JR \& Alexander M (1975) Microbial degradation of polyethylene glycols. Appl. Microbiol. 29: 621-625

International Union of Biochemistry Nomenclature Committee (Ed) (1984) Enzyme Nomenclature. Academic Press, Orlando FL USA

Kawai F (1985) Existence of ether bond-cleaving enzyme in a polyethylene glycol-utilizing symbiotic mixed culture. FEMS Microbiol. Lett. 30: 273-276

Kawai F, Yamanaka H, Ameyama M, Shinagawa E, Matsushita K \& Adachi O (1985) Identification of the prosthetic group and further characterization of a novel enzyme, polyethylene glycol dehydrogenase. Agric. Biol. Chem. 49: 1071-1076

Kawai F (1987) The biochemistry of degradation of polyethers. In: CRC Critical Reviews in Biotechnology, Vol 6 (pp 273307). Chemical Rubber Company Boca Raton FL USA

Lugtenberg B, Neijers J, Peters R, van der Hock P \& van Alphen L (1975) Electrophoretic resolution of the major outer membrane proteins of Escherichia coli $\mathrm{K}-12$ into four bands. FEBS Lett. 58: 254-255

Magee CM, Rodeheaver G, Edgerton MT \& Edlich RF (1975) A more reliable Gram staining technic for diagnosis of surgical infections. Am J Surgery 130: 341-346

Pearce BA \& Heydeman MT (1980) Metabolism of di(ethylene glycol) [2-(2'-hydroxyethoxy)ethanol] and other short poly (ethylene glycol)s by Gram-negative bacteria. J. Gen. Microbiol. 118: 21-27

Pfennig N (1978) Rhodocyclus purpureus gen. nov. and sp. nov., a ring-shaped, vitamin $B_{12}$-requiring member of the family Rhodospirillaceae. Int. J. System. Bacteriol. 23: 283288

Schink B, Bomar M (1991) The Genera Acetobacterium, Acetogenium, Acetoanaerobium, and Acetitomaculum. In: Balows A, Trüper HG, Dworkin M, Harder W \& Schleifer KH (Eds) The Erokaryotes, 2nd edn. Springer Verlag, New York (in press)

Schink B, Pfennig N (1982) Fermentation of trihydroxybenzenes by Pelobacter acidigallici gen. nov. sp. nov., a new strictly anaerobic, non-sporeforming bacterium. Arch. Microbiol. 133: 195-201

Schink B \& Stieb M (1983) Fermentative degradation of polyethylene glycol by a strictly anaerobic, Gram-negative, nonsporeforming bacterium, Pelobacter venetianus sp. nov. Appl Environ. Microbiol. 45: 1905-1913

Steber J \& Wierich P (1985) Metabolites and biodegradation pathways of fatty alcohol ethoxylates in microbial biocoenoses of sewage treatment plants. Appl. Environ. Microbiol. 49 : 530-537

Straß A \& Schink B (1986) Fermentation of polyethylene glycol via acetaldehyde in Pelobacter venetianus. Appl. Microbiol. Biotechnol. 25: 37-42

Thélu J, Medina L \& Pelmont J (1980) Oxidation of polyoxyethylene oligomers by an inducible enzyme from Pseudomonas P 400. FEMS Microbiol. Lett. 8: 187-190

Toraya T, Honda S \& Fukui S (1979) Fermentation of 1,2Ethanediol by some genera of Enterobacteriaceae involving Coenzyme $\mathbf{B}_{12}$-dependent diol dehydratase. J. Bacteriol. 139: $39-47$

Toraya T, Krodel E, Mildvan AS \& Abeles H (1979) Role of peripheral side chains of vitamin $B_{12}$ coenzymes in the reaction catalyzed by dioldehydrase. Biochemistry 18: 417-426

Toraya T \& Fukui S (1982) Diol dehydrase. In: Dolphin D (Ed) $\mathrm{B}_{12}$, Vol 2 (pp 233-266). John Wiley and Sons, New York

Wagener S \& Schink B (1988) Fermentative degradation of nonionic surfactants and polyethylene glycol by enrichment cultures and by pure cultures of homoacetogenic and propionate-forming bacteria. Appl. Environ. Microbiol. 54: 561-565

Widdel F \& Pfennig N (1981) Studies on dissimilatory sulfatereducing bacteria that decompose fatty acids. I. Isolation of new sulfate-reducing bacteria enriched with acetate from saline environments. Description of Desulfobacter postgatei gen. nov. sp. nov. Arch. Microbiol. 134: 286-294

Widdel F, Kohring GW \& Mayer F (1983) Studies on dissimilatory sulfate-reducing bacteria that decompose fatty acids. III. Characterization of the filamentous gliding Desulfonema limicola gen. nov. sp. nov., and Desulfonema magnum sp. nov. Arch. Microbiol. 134: 286-294

Zehnder AJB \& Wuhrmann K (1976) Titanium-III-citrate as a nontoxic oxidation-reduction-buffering system for the culture of anaerobes. Science 194: 1165-1166 